\title{
Perceived Influence of Toothpaste Repackaging on Purchase Predisposition of Customers in Owo, Ondo State
}

\author{
Kolade Ajilore \\ Babcock University, Ogun State, Nigeria \\ Christiana Shade Ade-Johnson \\ AdekunleAjasin University, Ondo State, Nigeria
}

\begin{abstract}
Packaging has advanced from being preserver of products to being a visible billboard and a silent salesman for products. This has made the manufacturers to keep repackaging their products especially toothpaste. The paper therefore examines perceived influence of the toothpaste repackaging on the purchase predisposition of the residents of Owo Local Government Area using Mymy, Close Up, Macleans and Pepsodent as case study. Survey design was employed for the study while two hundred copies of questionnaire were administered to two hundred respondents who were selected through purposive sampling. The finding revealed that there is significant influence of change in packaging of tooth paste on the consumers' purchase predisposition which may invariably lead to purchase of these brands of tooth paste. The study therefore recommends that manufacturers should introduce changes in elements of tooth paste carefully and gradually in order to study the consumers' reaction to such change.
\end{abstract}

Keywords: packaging, repackaging, consumer behaviour, view model

\section{Introduction}

Packaging has advanced from being used as the preserver of goods to being used as visible billboard (Kotler \& Keller, 2009). Thus, it is now employed as an element of marketing strategy in order to make profit and this has become the focus of many manufacturers for expanding markets, attracting new customers and retaining existing ones. The ability to be able to position one's brand to the consumers in a well attractive package amid other thousands of choice remains one of the best options. Kotlerand and Keller (2009) stress the fact that consumers are faced with 20,000 choices within a 30-minute shopping session. With so many options available at the point of purchase, packaging remains the only final communication with the consumers since people believe that "you buy the package and use the product". So, packaging becomes an element of product strategy that has become important to create a minute difference in the brands as innovative packaging may provide a competitive advantage (Kotler, 2009).

Consequently, at the point of purchase, the product package becomes the communication life-blood of the firm. The package, sometimes referred to as the "silent salesman", makes the final sales pitch, seals the commitment and gets itself placed in the shopping trolley (Hine, 1995). Harckham (1989) noted that the package is the shopper's window to the product because it often projects the initial impression they form about

Kolade Ajilore, Ph.D., Msc, Bsc Mass Communication, Department of Mass Communication, Babcock University.

Christiana Shade Ade-Johnson, Ph.D. in view, MA, BA Mass Communication, Department of Mass Communication, AdekunleAjasin University. 
a product, its quality or its value. Product managers and design firms therefore seek to create packages that break through the clutter of the market-place and communicate all positive and necessary benefits to the consumer. The ability of brands to gain attention and consideration at the point-of-purchase seems to form the basis for design strategy, which is particularly important in the case of new brand introductions, brand repositioning, brand extensions and the signalling of product changes (Garber, 1995). These major facts have made the FMCG manufacturers to keep repackaging their products especially tooth pastes.

Repackaging simply means the process of packaging something again or anew. It involves changes in size, colours, design and any other features of the product. Its success depends a lot on how it is designed by its creators. Perhaps it has the power to influence consumers' choices, and with its carefully thought-out aesthetics, it can affect their emotions which invariably influence the purchase decision of the consumers. Almost all the manufacturers of tooth paste have repackaged their products ranging from Close up, MacLeans, Mymy to Pepsodent. Indeed, change has always been with the marketing world, but this new swift pace demanded fast action and a new orientation, even consumers get dissatisfied with the same old design, old brands, old services and old habits yet, a product that meets a consumer's need at just the right time may rise in performance than others in the market (Oladele, 2013) considering the consumers' belief and expectation that such products would deliver a better quality than before when such products repackaged.

\section{Statement of the Problem}

Decades back, manufacturers adopted and are still adopting various packages for their products. Consequently, consumers have been overwhelmed with diverse conceptions resulting into changes in packaging of products especially the tooth pastes. Many of them are resized, remixed or repositioned; others change the colour, product information and designs. The change in package of tooth paste products is intended to attract new consumers; old consumers are also persuaded to remain loyal to brands. As a result, consumers are in a tough spots as they are exposed to different window of information and varieties of products; many great deal of choices and options available in the market place, diverse selections of tooth pastes clamouring for attention, invariably lead to confusion about what brand of product to buy, what product to buy as they are mindful of their purchasing power. However, these consumers are perhaps made up of both literates and illiterates in urban and rural areas. The packages are always full of information and designs targeted at these consumers not minding the level of their understanding. The questions that are germane to this discourse are: Are the demographic factors of these targeted consumers put into consideration while repackaging the tooth paste products? Do these consumers able to decode the messages on the packages of these products? Does this repackaging of tooth paste products affect their buying behaviour? The aim of this study is to find out the influence of changes in product package most especially tooth paste on consumers' purchase behaviour.

Owo is the headquarters of Owo Local Government Area of Ondo State. It is located about 45 kilometers East of Akure, the Ondo State Capital. Owo lies on latitude 70 15' North of the Equator and longitude 50 35' East of Greenwich Meridian. The population of the study area is one hundred and twenty thousand. Agriculture forms the mainstay of the economy of Owo local government area, making the people of Owo area predominantly farmers. They cultivate mostly cash crop like cocoa, cashew food crops like yam, cocoyam, maize, cassava, and vegetables. The secondary productive sector of the economy of Owo is dominated by medium and small scale agro-manufacturing activities and activities like saw milling industries. The people of Owo are communal in their behaviour. Even though Owo has some secondary schools, Private University, a 
State Polytechnic, Teacher Training College, a government trade institute, a museum, and several hospitals, the mindset is still relatively local.

\section{Research Questions}

- Which of the elements of packaging are prominent among respondents?

- To what extent does the change in elements of tooth paste package affect consumers' purchase behaviour?

- What other factors inform consumers' purchase of tooth paste?

\section{Research Hypotheses}

- H1: Elements of tooth paste packaging significantly influence consumers' purchase behaviour.

- H2: Tooth paste Repackaging significantly influence consumers' purchase behaviour.

- H3: Demographic features of consumers significantly influence tooth paste purchase behaviour.

- H4: Demographic features of consumers significantly influence consumers' perception of reasons for tooth paste repackaging.

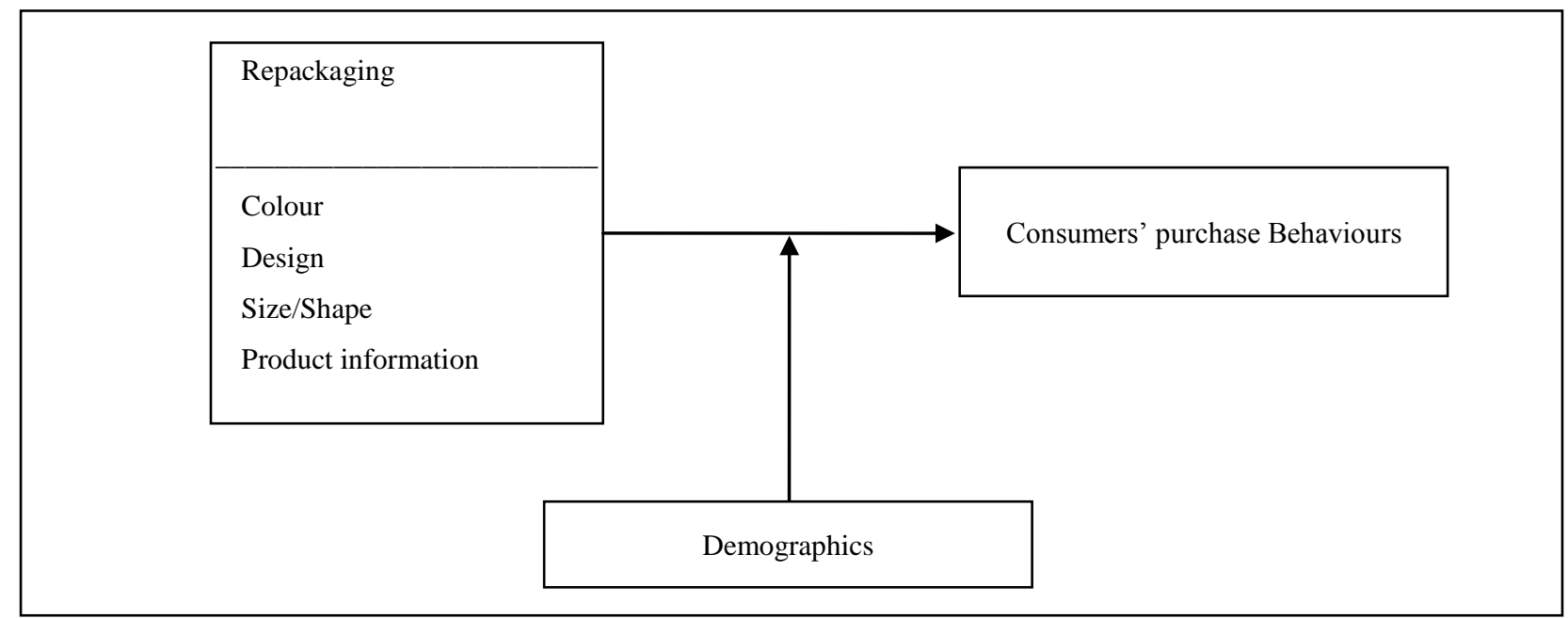

Figure 1. Proposed Research Framework.

\section{Ajilore\&Ade-Johnson (2015) Conceptual Model on Repackaging of Tooth Paste}

The model in Figure 1 hypothesizes that elements of tooth paste packaging significantly influence consumers' purchase predisposition (H1). Also, the model postulates that change in packaging of tooth paste significantly influence consumers' purchase predisposition (H2). Furthermore, this model proposes that demographic factors of consumers as intervening variables of tooth paste significantly influence on consumers purchase predisposition of tooth paste. Lastly, the conceptual model posits that demographic factors of tooth paste consumers significantly influence the reasons that consumers have for change in packaging of tooth paste.

\section{Literature Review}

\section{Packaging}

Packaging has become a potent marketing tool and its role has evolved from the traditional function of protecting the products through distribution channels against damage, dirt, theft, mishandling and deterioration. In this modern era, it is now used to arouse and stimulate consumer's attention, and to promote as well as 
convey relevant messages about the product's features with the use of creative techniques that engage consumers whilst still on the shelf or at the point of sale (Kotler, 2008).

It therefore, stands quite clear then that the skill and creativity of package design professionals, marketers and designers, is becoming increasingly relevant as it brings the physical elements of the product together and allows for a creative construction of how a product is presented. So, if this is executed in a skilful way consumers often choose products based on the packaging fulfilling the aphorism that consumers "buy the package and use the product" (Nickels \& Jolson, 1977, p. 14). This view enforces the estimate that seventy three percent of purchase decisions are made at point of sale (Rettie \& Brewer, 2000) as some believe that package is the first and almost always the last moment of truth before a purchase is made.

For manufacturers, the functions of package design must be able to sell the brand while creating image and customer perception. The saying "you only get one chance to make a good first impression" fits well into the package design market, companies most especially tooth paste producers now use packaging as a tool of sales communication that often can lead to impulsive buying behaviour (Kuvykaite, 2009).

\section{Elements of Packaging}

There are many different classifications of elements of package in the past research works. Smith and Taylor (2004) mentioned six variables that are taken into consideration by manufacturers and designers when creating efficient package: form, size, colour, graphics, material and flavour. Similarly, Kotler (2003) distinguishes six elements that must be evaluated when employing packaging decisions: size, form, material, colour, text, and brand. In corroborating this view, Silayoiand and Speece (2007) go a step further to specifically mention the elements of package as visual elements (graphics, colour, shape, and size) and informational elements (information provided and technology). Therefore this discourse will identify with definition of Silavoiand and Speece (2007) of elements of packaging.

So, it is essential that these packaging elements which include texts, colours, structure, images and people/personalities are combined to provide the consumer with visual sales negotiation when purchasing and using the product (Nancarrow, Wright, \& Brace, 1998; McNeal \& JI, 2003).

\section{Repackaging}

Repackaging means a change in all or some of the elements of product package. These elements include colour, size, shape, design and information about the product or the manufacturer. Most times, it seems when manufacturers repackage their mouth paste products, not all the elements of the package are included. There are at times when the products are repackaged in small sizes and shapes while the other elements of package remain the same. However, whenever there is repackaging, the manufacturers use the opportunity to pass information across to the consumers about the change of ingredients and benefits to be derived from the product thereby raising the hope or expectation of the consumers for better value. According to Okoroma (2014) repackaging of information refers to the "presentation of information in a most understandable, reliable, acceptable and usable forms". For manufacturers to have positive responses from the consumers, not just the information provided in words is adequate, the use of non-verbal cues which made up the elements of product package passes across messages to consumers. To this end, all intended messages should be more understandable, reliable, acceptable and in usable forms.

\section{Consumer Behaviour}

Consumer behaviour is defined as the study of processes involved when individual or groups select, 
purchase, use, or dispose of the product, service, ideas or experiences to satisfy needs and desires (Solomon, 1998; Noel, 2009). Okigbo (1990) position on consumer behaviour points to the mental processing of information, selection of benefits and post purchase. For every acquisition, usage and disposal of repackaged product, there are mental, physical and emotional processes involved in every stage. Consumers do not buy goods without background knowledge of why they have to take any action.

A variety of factors shape consumers purchase decisions (Kotler \& Keller, 2009). Studies showed that a consumer's buying behaviour is influenced by cultural, social, personal and psychological factors. Qjeahere (2004, p. 44) citing Arens, mentions unpredictable individual behaviour as one of the factors that influence consumer behaviour. Many consumers consider self image or status among other variables before making any purchase decisions. Noel (2009) categorises the factors that affect consumer behaviour into three groups:

- External factor;

- Internal processes (including consumers decision making);

- Post decision processes.

External influences focus on the various factors that affect consumers as they identify which needs to satisfy (the use of mouth paste) and which products (whether close up. Mymy, or Macleans or other brands of tooth paste) to use to satisfy those needs. According to Noel (2009) these forces fall into two major categories: the efforts of the firm; and the various factors that make up the consumer's culture. The marketing efforts of the firm include the product being offered for sale, its price, the places it's offered for sale, and how they choose to promote it. These forces are fairly uniform, regardless of the individual needs and background of the consumer. Nevertheless, it is not only factors that made up consumer's culture that could affect the buying process, the demographic and other psychographic factors could also be responsible like age, education status, gender, lifestyles and income.

The internal factors highlight the psychological factors inherent in each consumer. These psychological factors are motivation (inner state of arousal), perception, and knowledge: reflects the information an individual gathers about different brands, companies, product categories, how to buy products and also how to use products, attitude which Noel (2009) believes may not necessary lead to purchase and memory.

Post decision processes involve the process of recognising problem of need by the consumer, information search, judgment and decision making. Perhaps the manufacturers of mouth paste recognise these processes and decide to repackage their brands into other sizes, changing colours, designs, graphics and even promises about their brands.

\section{Demographic Features of Consumers}

Consumers' composition may be described in terms of basic demographic features-age, sex, family, gender, life cycle, income, and other characteristics such as education, occupation, religion and nationality (Awunyo-Vitor, Ayimey, \& Gayibor, 2013). Demographics of consumers are vital statistics as play an important role in the consumer purchase process as well as influence decision making at every step in the process. As a result, demographic features of consumers are useful to marketers in order to effectively target them.

Alooma and Lawan (2013) while studying the effect of demographic factors, state that buying behaviour of consumers would depend on the age group: the features younger consumers would look for in clothes may not be the same with older consumers. Therefore, marketers have found age, for instance, to be a particular 
useful demographic variable for distinguishing market segments, largely because products needs and interests often vary with consumers' age. It is believed that older people consider diversified option through the experience they have developed and younger ones with less experience rely on brand and price (Paul, Trun, \& Alan, 1996).

Similarly, gender is assumed to differentiate consumption behaviour. Ekeng, Lifu, and Asinya (2012) assert that females are more predisposed to shopping for domestic and family needs than men. This may be that "women and men perform different roles in every household; they have different demands for certain products as well as they behave differently in the process of consumption" (Dorota, 2013, p. 25). Contradicting this opinion, "Global PL-Trande" (2010) reports that gender has no influence on the buying behaviour.

Also, Dorota (2013) reports income as the superior determinant of purchasing behaviour of consumers. It means that the level of income affect the life style and attitude of a consumer. A person with high income would like to buy product with high price and those with low income prefer to buy product with lower price (Paul, Trun, \& Alan, 1996). Other Literature discusses the effect of income on deal proneness along the same line as the education effect. Expanding on how the educational status of consumers can influence their purchase behaviour, Khaniwale (2015, p. 287) posits that "an educated person tends to make wise decisions as compared to an uneducated person". This may be as a result of the ability to collect process and analyze information.

\section{View Model}

Twedt (1968) propanded the VIEW model to assess packaging in relation to expected performance and contribution in the promotional mix. The VIEW concept of packaging, as enunciated by Twedt, prescribes four criteria for evaluating a package before it could influence consumers' behaviour, attitude, and opinions about a product. These criteria include Visibility (V), Information (I), Emotional appeal (E), and Workability (W)

- Visibility: The visibility of the package of a product shows its ability to attract the customers' attention at the point of purchase; and to stand out among the packages of the other products or other brands of the same product category that are displayed on the shelf (Hine, 1995; Rowan, 2000). It depends on factors like colors, new and attractive design, shape and size, which attract attention. In the case of mouth paste product: MyMy, Close up, Pesodent and Macleans which are always displayed together, with the change in packages, are they able to stand out in the midst of cluttered shelf and other products?

- Information: Information of the packaging is related to the quantity and quality impact of the product. It tends to know if the product usage instructions, claimed benefits, slogans, and supplementary information are able to influence the consumers at point of purchase. Its extent is determined by the degree to which the information identifies the product, gives the quality of the product and its contents, gives instructions how to use it (and shows the expiry date), gives information about the manufacturer or seller, and has an attractive and impressive design. The manufacturer while trying to package useful and stimulating information for trial and repeat purchase must avoid cluttering the package of the product with excess information (Engel, Warshaw, \& Kinnear, 1979).

- Emotional appeal: The emotional appeal of the package is related to its ability to arouse the emotions and mood desired by the seller. It depends on the presence of a color with a positive impact (not only bright but attracting attention) as well as on the material from which it is made, the shape of the package, which should also have a positive effect on the emotions of people. In this 21 st century, manufacturers tend to change the shape of the products to oval trying as much as to reflect feminism in the nature of the package. 
- Workability of package: This reflects its ability to carry out its main function - to contain and protect the product content, to make its transportation and storage easier and to make the purchase and its usage simpler for the consumers. The package should be able to simplify the consumer's task in accessing and using the product? It should also be environmentally friendly.

\section{Methodology}

Survey design was employed. The target population; residents of Owo Local Government Area comprised of one hundred and twenty thousand people. The local government area is made up of five towns. Purposive sampling was employed to select two hundred respondents from two markets in Owo Local Government Area who are buyers of any of the four mouth paste products included in the study. Two hundred copies of questionnaire were given to all the selected respondents. The researcher with the help of two assistant researchers personally administered the copies of the questionnaire to the respondents at the two market outlets.

\section{Data Analysis and Interpretation}

From Table 1, majority of the study participants were males $(n=129,64.5 \%)$, while females constituted $35.5 \%(n=71)$. Majority of study participants were adults $(n=157,78.5 \%)$, few participants were between 16 and $20(n=28,14 \%)$ and the remaining participants $(n=15,7.5 \%)$ were below age 16 . Furthermore, majority of the study participants were single $(n=183,91.5 \%)$ while those who were married had little representation $(n$ $=17,8.5 \%)$. Those with SSCE $(n=100,50 \%)$ were the major participants in this study whereas HND/B.Sc. and above constituted $(n=40,20 \%)$ each and the remaining participants were $(n=20,10 \%)$. Majority of the participants were civil servant $(n=105,52.5 \%)$, followed by drivers $(n=56,28.0 \%)$, hairdressers and traders constituted $(n=18,9.0 \%)$ each while three participants did not give any response. Consequently, there are more male views represented in the study. The findings also indicate that predominant opinions in this study are those of singles. The study also connotes that a sizeable percentage of the respondents were educated who were able to comprehend and respond to the items in the questionnaire. It is also evident that the majority of the participants in the study were adults.

Table 1

Respondents' Demographic Details

\begin{tabular}{lll}
\hline Variables & Frequency & Percent \\
\hline Gender & & \\
\hline Female & 71 & 35.5 \\
Male & 129 & 64.5 \\
Total & 200 & 100.0 \\
\hline Age & & \\
\hline Below 16 & 15 & 7.5 \\
16 and 20 & 28 & 14.0 \\
Adult & 157 & 78.5 \\
Total & 200 & 100.0 \\
\hline Marital Status & & \\
\hline Single & 183 & 91.5 \\
Married & 17 & 8.5 \\
Total & 200 & 100.0 \\
\hline
\end{tabular}


(Table 1 continued)

\begin{tabular}{lll}
\hline Variables & Frequency & Percent \\
\hline Educational background & & \\
\hline Below SSCE & 20 & 10 \\
SSCE & 100 & 50 \\
HND/B.Sc & 40 & 20 \\
Above B,Sc & 40 & 20 \\
Total & 200 & 100.0 \\
\hline Occupation & & \\
\hline Drivers & 56 & 28.0 \\
Civil servant & 105 & 52.5 \\
Hairdressers & 18 & 9.0 \\
Traders & 18 & 9.0 \\
Missing & 3 & 1.5 \\
Total & 200 & 100.0 \\
\hline
\end{tabular}

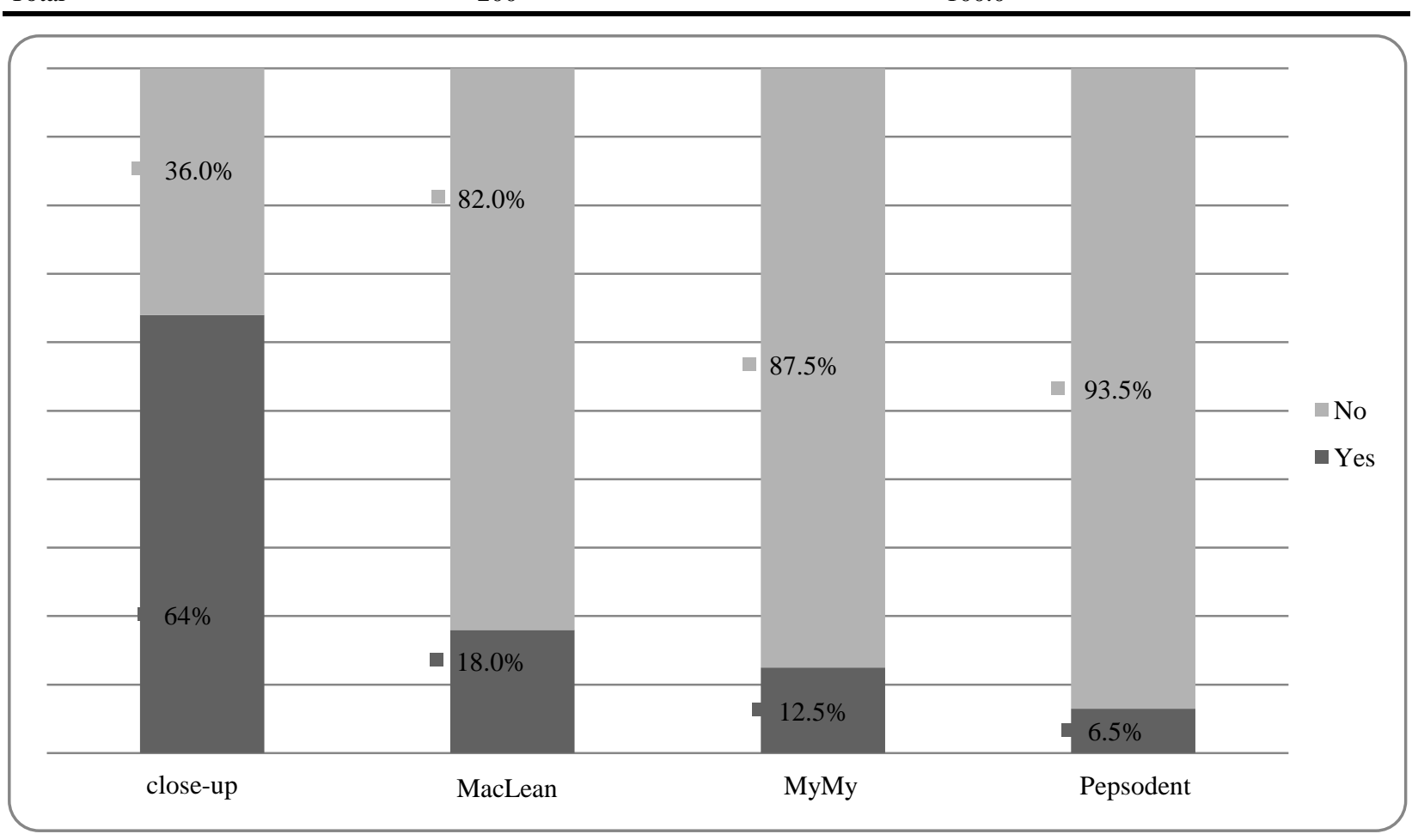

Figure 1. Distribution of Respondents by Tooth Pastes.

Figure 1 illustrates that majority of the study participants were Close-Up tooth paste users $(n=128,64 \%)$ followed by users of MacLean $(n=36,18 \%)$, MyMy $(n=25,12.5 \%)$ while respondents who are users of Pepsodent $(n=13,6.5 \%)$ had the smallest proportion of representation. The findings reveal that Close-Up are more common than any other brands of tooth paste in Owo, Owo Local Government Area of Ondo State. The pattern of findings might have been traceable to marketing communication activities of each brand in the market. Close-Up and Macleans are the market leaders in this category and Advertising campaign is highly visible

From Table 2, majority of the respondents $(91.5 \%)$ stated that they could understand the information on the package of the product. 
Table 2

Respondents Who Understand the Information on the Package of the Product

\begin{tabular}{lcc}
\hline Variable & Frequency & Percent \\
\hline Yes & 183 & 91.5 \\
No & 6 & 3.0 \\
Missing & 11 & 5.5 \\
Total & 200 & 100.0 \\
\hline
\end{tabular}

Research Question One: Which elements of packaging are most prominent among respondents?

Table 3

Prominent Elements of Tooth Paste Packaging

\begin{tabular}{|c|c|c|c|c|c|c|}
\hline ITEMS & SA & A & $\mathrm{D}$ & SD & $\mathrm{U}$ & Mean \\
\hline Flavour & $\begin{array}{l}109 \\
(54.5)\end{array}$ & $\begin{array}{l}78 \\
(39) \\
\end{array}$ & $\begin{array}{l}10 \\
(5) \\
\end{array}$ & $\begin{array}{l}3 \\
(1.5) \\
\end{array}$ & - & 1.5350 \\
\hline Colourful & $\begin{array}{l}110 \\
(55) \\
\end{array}$ & $\begin{array}{l}72 \\
(36) \\
\end{array}$ & $\begin{array}{l}14 \\
(7) \\
\end{array}$ & $\begin{array}{l}4 \\
(2) \\
\end{array}$ & - & 1.5600 \\
\hline Product and manufacturers' information & $\begin{array}{l}115 \\
(57.5) \\
\end{array}$ & $\begin{array}{l}65 \\
(32.5) \\
\end{array}$ & $\begin{array}{l}8 \\
(4) \\
\end{array}$ & $\begin{array}{l}6 \\
(3) \\
\end{array}$ & $\begin{array}{l}6 \\
(3) \\
\end{array}$ & 1.5808 \\
\hline Unique Design & $\begin{array}{l}80 \\
(40) \\
\end{array}$ & $\begin{array}{l}74 \\
(37) \\
\end{array}$ & $\begin{array}{l}23 \\
(11.5)\end{array}$ & $\begin{array}{l}17 \\
(8.5) \\
\end{array}$ & $\begin{array}{l}6 \\
(3) \\
\end{array}$ & 1.9750 \\
\hline Different Sizes & $\begin{array}{l}61 \\
(30.5) \\
\end{array}$ & $\begin{array}{l}72 \\
(36) \\
\end{array}$ & $\begin{array}{l}47 \\
(23.5)\end{array}$ & $\begin{array}{l}18 \\
(9) \\
\end{array}$ & $\begin{array}{l}2 \\
(1)\end{array}$ & 2.1400 \\
\hline Unique Shape & $\begin{array}{l}82 \\
(41)\end{array}$ & $\begin{array}{l}44 \\
(22)\end{array}$ & $\begin{array}{l}43 \\
(21.5)\end{array}$ & $\begin{array}{l}19 \\
(9.5)\end{array}$ & $\begin{array}{l}12 \\
(6)\end{array}$ & 2.1750 \\
\hline
\end{tabular}

Notes. SA= Strongly Agree coded 1, A = Agree coded 2, D = Disagree coded 3, SD = Strongly Disagree coded 4, U = Undecided coded 5 .

From Table 3, majority of the respondents stated that colour, size, shape, design, manufacturers and product information, and flavour of tooth paste elements of packaging are all very important to them. This is because $93.5 \%$ of the respondents agreed that their tooth pastes had unique flavour, $91 \%$ agreed that their tooth pastes has colour, 90\% agreed that their tooth pastes included product and manufacturers' information, $77 \%$ agreed that their tooth pastes had unique designs, $66.5 \%$ also agreed that their tooth pastes had different sizes and finally, $63 \%$ of the respondents agreed that their tooth pastes had certain shape.

Research Question Two: How does change in product package affect consumer's purchase behaviour?

From Figure 2, majority of the study participants did not agree with the assertion that the colour, size, shape, design, product and manufacturers' information and flavour of their tooth pastes are changed often.

Figure 3 depicts that majority of the study participants did not agree that changes in their mouth pastes' colour, size, shape, design, product and manufacturers' information and flavour have led to the purchase of tooth pastes.

Research Question Four: What other factors inform consumers' purchase of tooth paste?

From Figure 4, majority of the study participants stated that quality $(80.5 \%)$ was the singular most important reason that made them bought a particular tooth paste. 


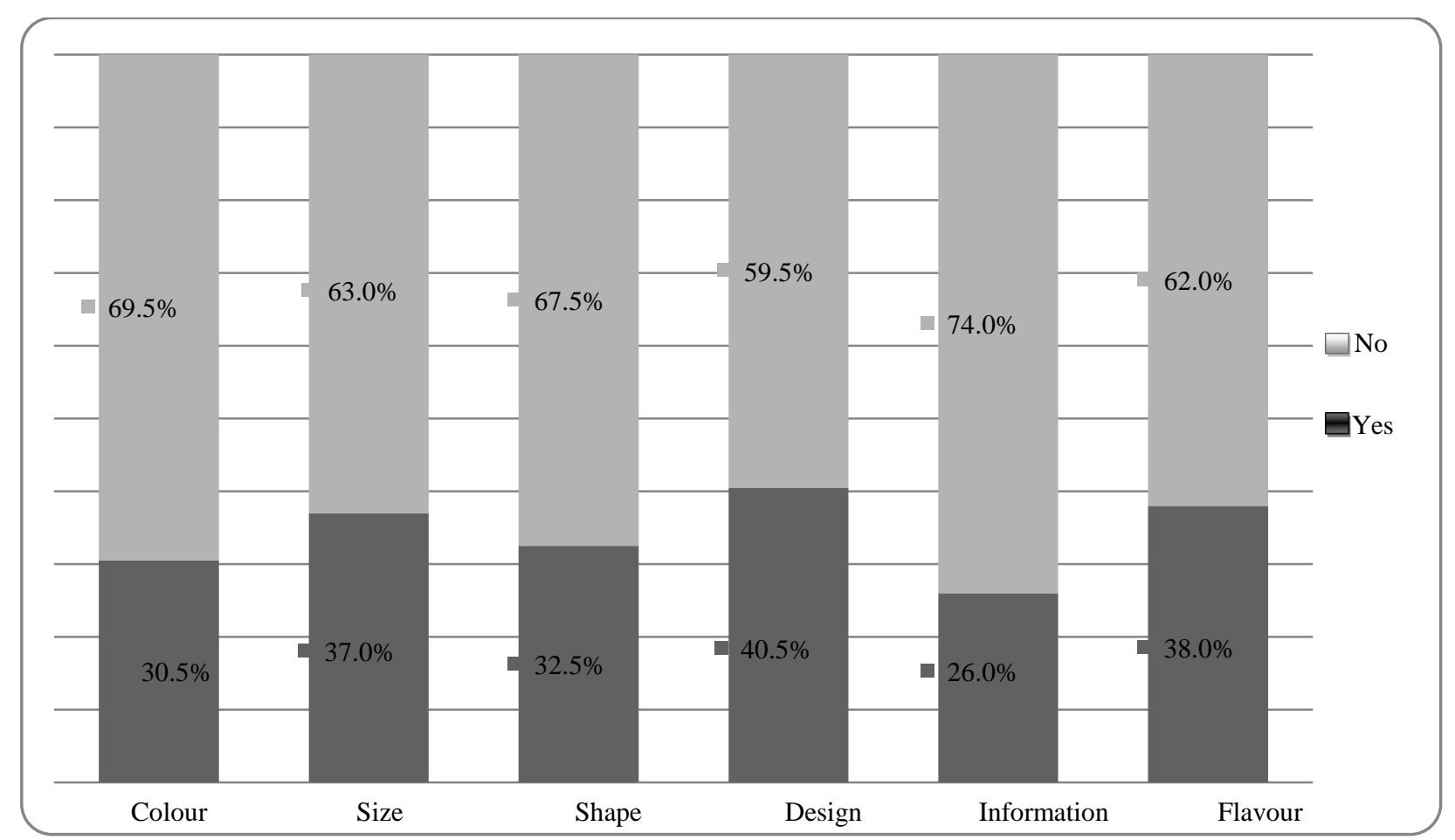

Figure 2. Change in elements of Tooth Paste Packaging.

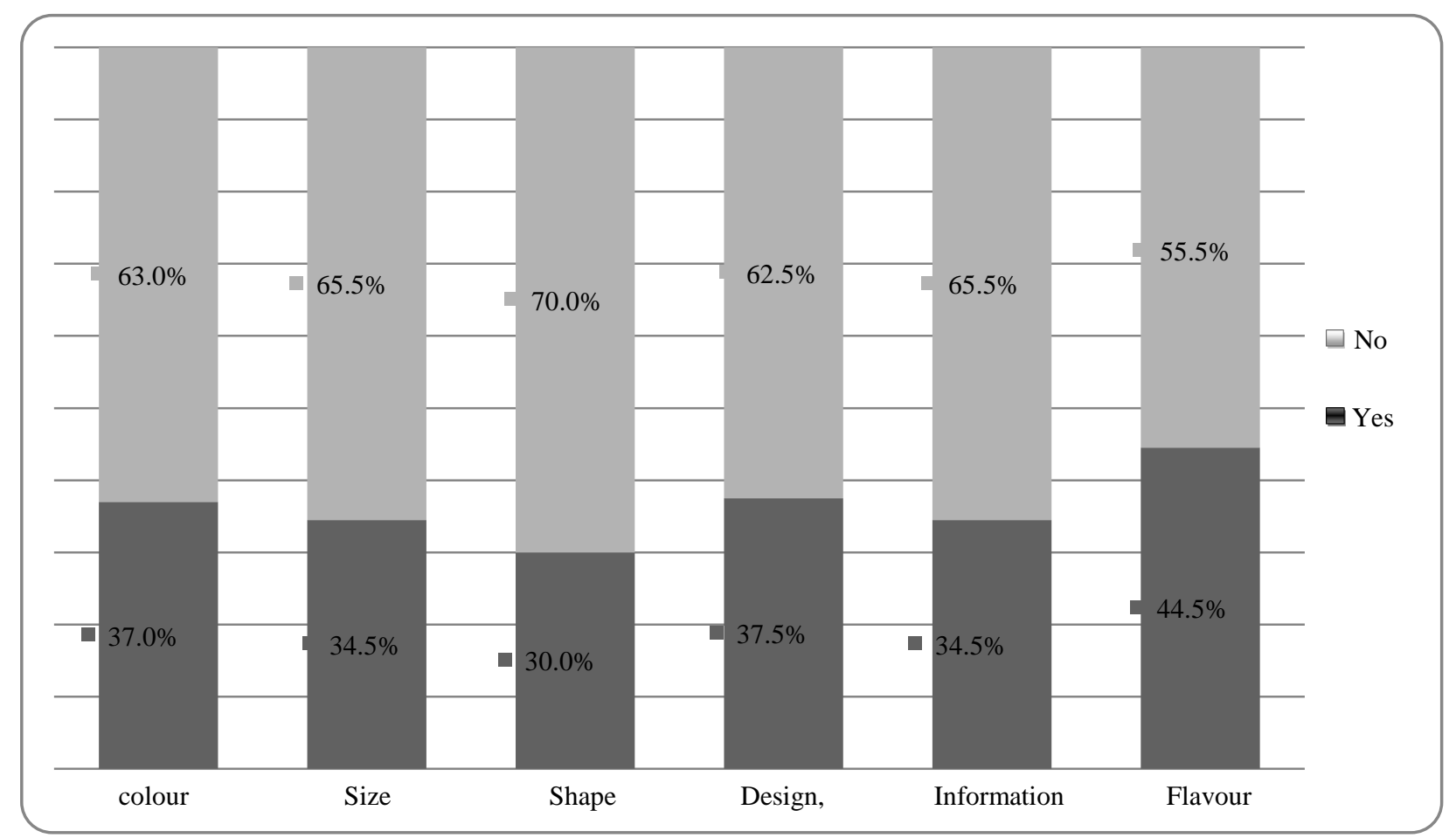

Figure 3. Change in Tooth Paste Packaging and Consumer Purchase Behaviour. 


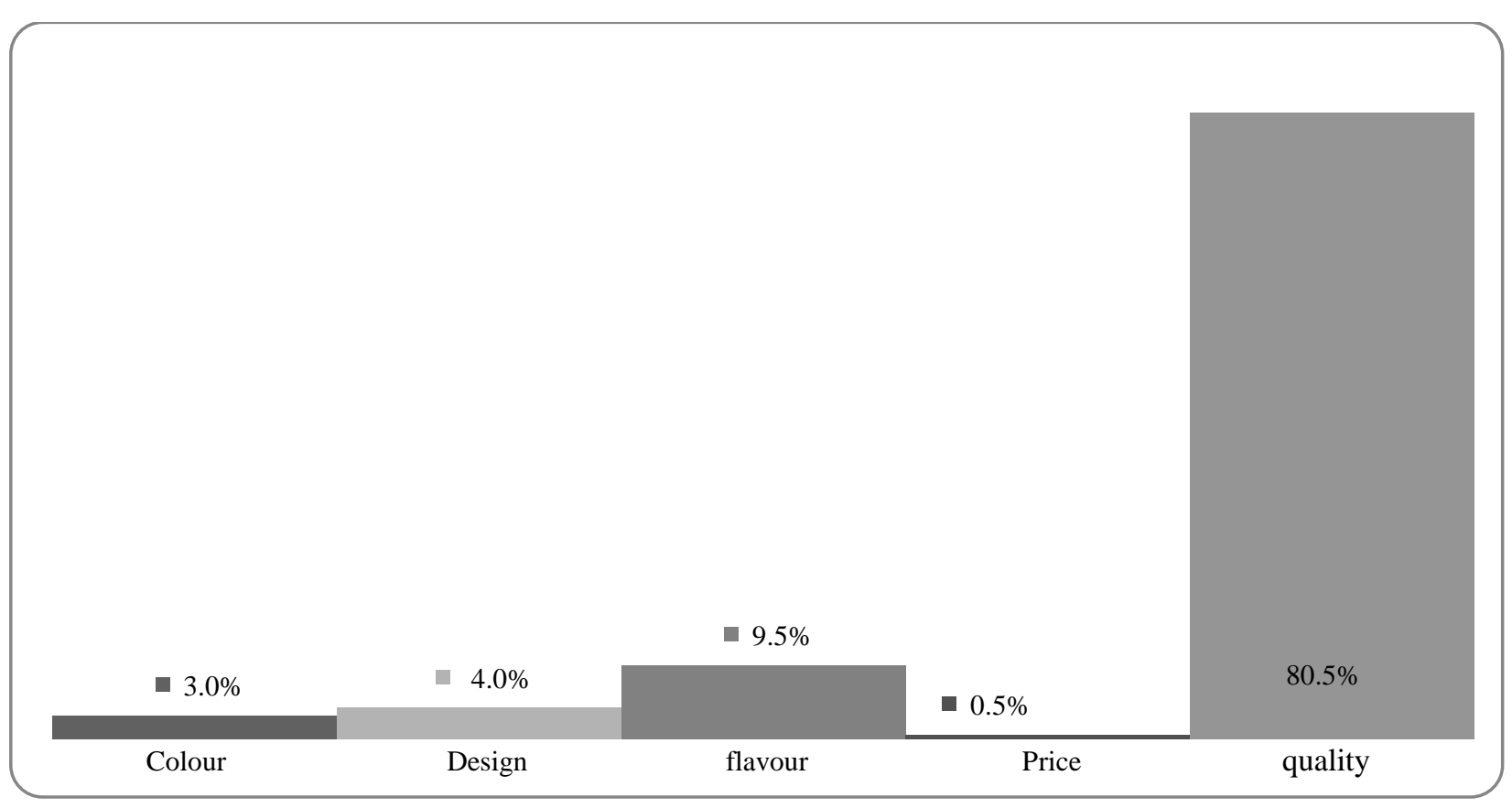

Figure 4. Reasons Respondents Purchased their Preferred Mouth Paste.

\section{Test of Hypotheses}

\section{Decision Rule}

The pre-set level of significance for this study is 0.05 . The hypothesis assumes that there is a relationship or effect exists between the variables under consideration. If the P-value (that is, the significance or the probability value) exceeds the pre-set level of significance (which is 0.05 ), the hypothesis will be rejected; but if the P-value is less than or equal to 0.05 , then the hypothesis will be accepted.

Hypothesis One: Elements of tooth paste packaging significantly influence consumers' purchase predisposition

Table 8

Influence of Elements of Tooth Paste Packaging on Consumers' Purchase Predisposition

\begin{tabular}{lllllll}
\hline \multirow{2}{*}{ Model } & \multicolumn{3}{c}{ Unstandardized Coefficients } & Standardized Coefficients & \multirow{2}{*}{ Sig. } \\
\cline { 3 - 6 } & B & Std. Error & Beta & & \\
\hline \multirow{2}{*}{1} & (Constant) & 12.493 & 1.385 & & 9.023 & 0.000 \\
& Elements of Tooth Paste Packaging & 0.384 & 0.118 & 0.227 & 3.252 & 0.001 \\
\hline
\end{tabular}

Notes. Dependent Variable: Consumer Purchase Predisposition; R Square $=0.051$.

Table 8 shows that elements of tooth paste packaging significantly influence consumers' purchase predisposition ( $p=0.001$ ), The model further indicates that elements of tooth paste packaging has a positive significant influence on consumers' purchase predisposition which suggests that a change in elements of tooth paste packaging will lead to a change in consumers' purchase behaviour and a change in consumer behaviour will lead to a change in elements of tooth paste packaging. The model however could only predict $5.1 \%$ of variation of influence on consumer purchase behaviour suggesting that there are other factors that are beyond the purview of this study. The implication of this analysis is that change in elements of tooth paste packaging could lead to either positive or negative consumer purchase predisposition which makes it imperative for tooth 
paste companies to introduce changes to elements of tooth pastes carefully and gradually in order to study consumers' reaction to such changes. Therefore, the hypothesis is accepted.

Hypothesis Two: Tooth paste repackaging significantly influence consumers' purchase predisposition.

Table 9

Influence of Mouth Paste Repackaging on Consumers' Purchase Predisposition

\begin{tabular}{|c|c|c|c|c|c|c|}
\hline \multirow{2}{*}{\multicolumn{2}{|c|}{ Model }} & \multicolumn{2}{|c|}{ Unstandardized Coefficients } & \multirow{2}{*}{$\begin{array}{l}\text { Standardized Coefficients } \\
\text { Beta }\end{array}$} & & \multirow{2}{*}{ Sig. } \\
\hline & & B & Std. Error & & & \\
\hline \multirow{2}{*}{1} & (Constant) & 1.949 & 1.278 & & 1.525 & 0.129 \\
\hline & Tooth paste repackaging & 0.844 & 0.071 & 0.647 & 11.925 & 0.000 \\
\hline
\end{tabular}

Notes. Dependent Variable: Consumer Purchase Predisposition; R Square $=0.419$.

From Table 9, tooth paste repackaging, significantly influence consumers' purchase predisposition ( $p>$ $0.05)$. Furthermore, the model shows that tooth paste repackaging is highly correlated with consumer purchase behaviour $(\beta=0.647)$. The positive influence in this analysis suggests that an increase in mouth paste repackaging will lead to a proportional increase in consumer purchase behaviour, vice versa. The model could explain $41.9 \%$ of variation on consumer purchase behaviour, the implication of this is that whenever changes are made to tooth pastes' packaging, it causes consumers' behaviour to also change, this suggest that tooth paste companies should be very careful to ensure that changes that are made to tooth paste packaging will lead to positive change in consumer purchase behaviour rather than negative. Hence, the hypothesis is accepted.

Hypothesis three: Demographic features of consumers significantly influence mouth paste purchase behaviour.

Table 11

Demography and Consumer Purchase Predisposition

\begin{tabular}{|c|c|c|c|c|c|c|}
\hline \multirow[t]{2}{*}{ Model } & & \multicolumn{2}{|c|}{ Unstandardized coefficients } & $\begin{array}{l}\text { Standardized } \\
\text { Coefficients }\end{array}$ & \multirow[t]{2}{*}{$t$} & \multirow[t]{2}{*}{ Sig. } \\
\hline & & $\mathrm{B}$ & Std. Error & Beta & & \\
\hline \multirow{3}{*}{1} & (Constant) & 17.704 & 2.151 & & 8.230 & 0.000 \\
\hline & Gender & -0.010 & 0.851 & -0.001 & -0.011 & 0.991 \\
\hline & Marital Status & -0.882 & 1.454 & -0.043 & -0.606 & 0.545 \\
\hline
\end{tabular}

Notes. Dependent Variable: Consumer Purchase Predisposition; R Square $=0.002$; ANOVA $=0.832$.

Table 11 indicates that neither gender nor marital status of respondents had an individual or joint significant influence on consumer purchase predisposition $(p>0.05)$, this suggests that gender and marital status do not convincingly affect consumer purchase predisposition of tooth pastes. Therefore the hypothesis is rejected. In view of this study, it can be deduced that gender and marital status as demographic factors of consumers of mouth paste does not have significant influence on consumers' purchase behaviour of tooth paste.

Hypothesis four: Demographic features of consumers significantly influence consumers' perception of reasons for mouth paste repackaging.

Table 12 shows that neither gender nor marital status of respondents had an individual or joint significant influence on consumers' reasons for repackaging $(p>0.05)$. This suggests that gender and marital status do not to a large extent affect consumers' perception of reasons for repackaging mouth pastes. Therefore the hypothesis is rejected. 
Table 12

Demography and Consumer Reasons for Repackaging

\begin{tabular}{|c|c|c|c|c|c|c|}
\hline \multirow[t]{2}{*}{ Model } & & \multicolumn{2}{|c|}{ Unstandardized coefficients } & \multirow{2}{*}{$\begin{array}{l}\text { Standardized } \\
\text { Coefficients } \\
\text { Beta }\end{array}$} & & \multirow[t]{2}{*}{ Sig. } \\
\hline & & B & Std. Error & & & \\
\hline \multirow{3}{*}{1} & (Constant) & 6.420 & 0.740 & & 8.676 & 0.000 \\
\hline & Gender & 0.121 & 0.293 & 0.029 & 0.414 & 0.679 \\
\hline & Marital Status & 0.043 & 0.502 & 0.006 & 0.086 & 0.932 \\
\hline
\end{tabular}

Notes. Dependent Variable: Consumers' Reasons for Repackaging; R Square $=0.001 ;$ ANOVA = 0.914.

\section{Discussion of Findings}

This study examined the influence of repackaging of mouth pastes on consumers' purchase behaviour in Owo Local Government Area in Ondo State. It was discovered that change in packaging which also means repackaging of mouth pastes was not always implemented as marketing strategy.

Data obtained suggested that there were more males than females who visit markets to buy toothpastes. This finding contradicts the reports of Ekeng, Lifu, and Asinya (2012) who asserted that females are more predisposed to shopping for domestic and family needs than men. The majority of customers were adults from 16 and above; although there were a few minors who participated in the survey; these may represent those who probably were sent to purchase toothpaste by their parents from the markets. This study affirms the report of Alooma and Lawan, (2013) that buying behaviour of consumers would depend on the age group probably because of the fact that older people consider diversified option through the experience they have developed and younger ones with less experience rely on brand and price (Paul, Trun, \& Alan, 1996). Furthermore, the fact that majority of the respondents were literate implies that they were likely to be inclined to more modern oral care products like toothpastes other than the traditional means. Their level of literacy will also influences their ability to read packaging information so as to make informed decisions.

Furthermore, being a civil service working population with pockets of small and medium scale enterprises employers, income may likely be perceived to affect the brand and size of toothpaste to purchase. On the contrary, the respondents who are predominantly civil servants most preferred Close up which is much higher in price than MyMy. This implies that the respondents' choice of toothpaste to purchase was not influenced by price.

The findings from the study identify flavour as the prominent element of packaging that is important to tooth paste consumers thereby confirming the report of Smith and Taylor (2004) who included flavour. The study also agreed with the results from other studies (Rettie \& Brewer, 2000; Kotler, 2003) that colour, size, shape, design and product information are basically the elements of packaging. Manufacturers of tooth pastes should focus more on flavour while incorporating other elements of packaging. Also, it was discovered that manufacturers of tooth paste do not always change packaging of tooth paste, it could therefore be inferred that the few times in which manufacturers implement change in their brands of tooth paste should be able to call for attention which should invariably lead to purchase of the product.

Respondents also revealed that change in packaging does not lead to the purchase of tooth pastes to a great extent. However, the few consumers who agreed that they buy the tooth pastes whenever there is a change in packaging get motivated by features like colour, size, shape, design manufacturers' information and flavour. Perhaps this may be that people are slow to adapt change generally. 
Meanwhile, the respondents have ascribed quality of the product as most important reason for buying mouth paste brands. However, a good quality product that is packaged in an unattractive sub-standard container might not be visible enough to call the attention of the consumers at the point of purchase; as well as stand out among the packages of the other products or other brands of the same product that are displayed on the shelf. The manufacturers are advised therefore to combine good quality with good packaging that would fulfill the criteria of VIEW model.

Testing the hypotheses, it was gathered that elements of tooth paste packaging has a positive significant influence on consumers' purchase behaviour which suggests that a change in elements of tooth paste packaging will lead to a change in consumers' purchase behaviour and a change in consumer behaviour will lead to a change in elements of tooth paste packaging. This result agreed with Silayoi and Speece (2007). The implication of this analysis is that change in elements of tooth paste packaging could lead to either positive or negative consumer purchase behaviour which makes it imperative for tooth paste companies to introduce changes to elements of tooth pastes carefully and gradually in order to study consumers; reaction to such changes. Therefore, the hypothesis is accepted.

Consumers in Owo local government area also revealed in this study that changes in packaging of their tooth pastes influence their purchase behaviour positively since Beta is positive. However, it was discovered that demographic features of consumers of tooth pastes do not have influence on consumers' purchase behaviour in relation to repackaging of mouth pastes. This discovery contradict what Alooma and Lawan (2013), Ekeng, Lifu, and Asinya (2012) as well as Dorota (2013) and Paul, Trun, and Alan(1996) who posit that age and marital status have dominant influence on purchase behaviour of consumers.

\section{Conclusion}

The study examined the influence of repackaging of tooth paste on consumers' purchase behaviour using Mymy, Close up, Macleans and Pepsodent as case study. The study tested four hypotheses and four research questions. From the analysis and discussions, it was discovered that there is significant influence of change in packaging of mouth pastes on consumers' purchase behaviour which may invariably lead to purchase of these brands of mouth pastes.

\section{Recommendations}

In view of the above findings and discussions, the following recommendations are made:

(1) Manufacturers of tooth pastes should focus more on flavour while incorporating other elements of packaging whenever there is change in packaging of tooth pastes.

(2) The manufacturers are advised to combine good quality with good packaging that would fulfilled the criteria of VIEW model whenever they want to change their packaging of tooth pastes.

(3) Respondents also revealed that change in packaging does not lead to the purchase of tooth pastes to a great extent even though a change in packaging influences consumers' purchase behaviour. Manufacturers should therefore introduce changes to elements of tooth pastes carefully and gradually in order to study consumers' reaction to such changes.

\section{References}

Alooma, A., \& Lawan, L. (2013). Effects of consumer demographic variables on clothes buying behavior in Borno State, Nigeria. International Journal of Basic and Applied Science, 1(4), 791-799. 
Awosika, J. (2011). Can documentaries change the world. Memorable Articles of 2010, 225, 26-29.

Awunyo-Vitor, D., Ayimey, E. K., \& Gayibor, R. A. (2013). Does sales promotion influence buyer behaviour? A study of PZ cussons limited. British Journal of Economics, Management and Trade, 3(2), 141-152.

Brosekhan, A., \& Velayutham, M. (2013). Consumer buying behaviour-A literature review. IOSR Journal of Business and Management, 5, 8-16.

Dorota, R. (2013). Determinants of purchasing behaviour (pp. 333-346).

Ekeng, B., Lifu, F., \& Asinya, F. (2012). Effect of demographic characteristics on consumer impulse buying among consumers of Calabar Municipality, Cross River State. Academic Research International, 3(2), 1-7.

Engel, J., Warshaw, M., \& Kinnear, T. (1979). Promotional strategy. Illinois: Erwin, Inc.

Esiele, R. U. (1991). Consumer reaction to Maltina sales promotion. An M. A project, Department of Communication and Language Arts, University of Ibadan.

Garber, L. L. (1995). The package appearance in choice. Consumer Research, 22, 653-660.

Gilaninia, S., Ganjinia, H., \& Horadi, S. (2013). Effect of packaging elements on consumer purchasing decision (Case study Detergent market). Universal Journal of Management and Social Science, 3(8), 10-15.

Global Trade Organisation. (2010). World Trade Report. World Trade Organisation.

Harckham, A. (1989). Packaging strategy: Meeting the challenge of changing times. Pennsylvania: Lancaster.

Hine, T. (1995). The total package. Boston: Little, Brown \& Co.

Jowett, G. S., \& O’Donnel, V. (1986). Propaganda and persuasion. Newbury Park: Sage P Publication.

Kardes, F. R. (1999). Consumer behaviour and managerial decision making. New York: Addison-Wesley.

Khaniwale, M. (2015). Consumer buying behavior. International Journal of Innovation and Scientific Research, 14(2), 278-286.

Kotler, P. (2003). Marketing management: Analysis, planning and Control. New Jersey: Prentice-Hall Inc.

Kotler, P. (2009). Products, services, and brands: Building customer value. New Jersey: Prentice Hall.

Kotler, P., \& Keller, K. (2009). Marketing management. New York: Prentice Hall.

Kuvykaite, A. D. (2009). Impact of package elements on consumer's purchase decision. The Effect of Individualism on Private Economics and Management, 1, 441-458.

McNeal, J. U., \& JI, M. F. (2003). Children's visual memory of packaging. Journal of Consumer Marketing, 20(5), 400-27.

More, M. A. (2010). The important of product design and packaging in branding. Retrieved October 20th, 2015, from https://www.coatingexcellent.com

Nancarrow, C., Wright, L. T., \& Brace, I. (1998). Gaining competitive advantage from packaging and labelling in marketing communications. British Food Journal, 100(2), 110-118.

Nickels, W. G., \& Jolson, M. A. (1976). Packaging-The fifth "p" in the marketing mix?. Advanced Management Journal, 41(1), $14-20$.

Noel, H. (2009). Basic marketing consumer behaviour. Switzerland: AVA Publishing.

Ojeahere, o. o. (2004). Consumers' perception of advertisement: An assessment of advertising criticisms. An M. A project, Department of Communication and Language Arts, University of Ibadan.

Okigbo, C. (1990). Adevertising Copy and Layout. In C. Okigbo (Ed.), Advertising and Public Relations (pp. 75-89).

Okoroma, F. N. (2014). Information repackaging to target groups for a fee: A strategic plan. Education Journal, 3(5), 308-315.

Oladele, M. (2013). Influence of changes in packages on consumers' perception of product quality. An M. A project, Department of Communication and Language Arts, University of Ibadan.

Paul, S. R., Trun, K. J., \& Alan, D. (1996). House hold store brand proness: A framework. Journal of Retailing, 72(2), 159-185.

Rettie, R., \& Brewer, C. (2000). The verbal and visual components of package design. The Journal of Product and Brand Management, 9(1), 56-68.

Silayoi, P., \& Speece, M. (2007). The importance of packaging attributes: A conjoint analysis approach. European Journal of Marketing, 41(11), 1495-1517.

Smith, P., \& Taylor, J. (2004). Marketing communications: An integrated approach. London: Kogan Page.

Solomon, M. R. (1996). Consumer behaviour. New York: Prentice-Hall International.

Twedt, D. (1968). How much value can be added trough packaging. Journal of Marketing, 32(1), 61-65.

Vilčeková, L., \& Sabo, M. (2013). The influence of demographic factors on attitudes toward brands and brand buying behavior of slovak consumers. International Journal of Education and Research, 1(11), 1-10. 